\title{
Appendix 3: The Network of Delphic Honorands
}

\author{
No. 1. A Narrow Network (Central Greece, Attica and the \\ Peloponnese)
}

Number of sources revealing profession and origin of honorand(s): 84 decrees and 17 tituli honorarii.

TABLE 1 Chronological distribution of texts

\begin{tabular}{lc}
\hline Date & No. of sources \\
\hline 4th century BCE & 3 \\
3rd century BCE & 19 \\
2nd century BCE & 37 \\
1st century BCE & 11 \\
1st century CE & 9 \\
2nd century CE & 15 \\
Imp. & 6 \\
Undated & 1 \\
\hline
\end{tabular}

a This category includes inscriptions dated by the editors as imperial texts without any further date. 
TABLE 2 Professions of honorands originating from a narrow network

\begin{tabular}{|c|c|c|c|c|c|c|c|}
\hline Profession & $\begin{array}{l}4^{\text {th }} \\
\text { century } \\
\text { BCE }\end{array}$ & $\begin{array}{l}\text { 3rd } \\
\text { century } \\
\text { BCE }\end{array}$ & $\begin{array}{l}\text { 2nd } \\
\text { century } \\
\text { BCE }\end{array}$ & $\begin{array}{l}\text { 1st } \\
\text { century } \\
\text { BCE }\end{array}$ & $\begin{array}{l}\text { 1st } \\
\text { century } \\
\text { CE }\end{array}$ & $\begin{array}{l}\text { 2nd } \\
\text { century } \\
\text { CE }\end{array}$ & Imp. \\
\hline Public officials & 1 & 5 & 10 & 3 & 4 & 2 & \\
\hline Artists/musicians ${ }^{\mathrm{a}}$ & 1 & 7 & 10 & 3 & 2 & 3 & 2 \\
\hline 'Men of letters'b & & & 2 & 2 & 2 & 2 & 1 \\
\hline Foreign judges & 1 & 1 & 9 & 1 & & & \\
\hline Priests/temple stuff & & 1 & 2 & 1 & & 3 & 3 \\
\hline Athletes & & & 1 & & & & \\
\hline Monarchs & & $\begin{array}{l}\text { Areus of } \\
\text { Sparta }^{c}\end{array}$ & & & & & \\
\hline Physicians & & 1 & 1 & 1 & 1 & 1 & \\
\hline Military commanders & & 2 & 1 & & & & \\
\hline Other & & $\begin{array}{l}\text { wine } \\
\text { maker }\end{array}$ & & & & $\begin{array}{l}\text { architect;" } \\
\text { sculptor; } \\
\text { Herodes } \\
\text { Atticus and } \\
\text { his familyg }\end{array}$ & \\
\hline
\end{tabular}

a Following Bouchon (2013, 72), against Bouvier (1985, 119-135), I include poets among artists and musicians, as many of them composed poems which were destined to be presented during the Delphic festivals.

b Teachers, historians, grammarians, philosophers.

c FdD 4.418. Flacelière 1937, 457-8; Choix 2012, no. 76 .

d $F d D$ 2.210.

e FdD 4.96. Donderer 1996, A39; Hellmann 1999, 24; Choix 2012, no 292.

f $F d D$ 2.118.

$\mathrm{g}$ It is difficult to classify Herodes Atticus and his relatives to one of the following categories, since it is insufficient to describe him only as a public official. Therefore, I decided to list him in the category 'other'. See FdD 3.66-74. Ameling 1983, nos. 103-110 and 176; Choix 2012, nos. 256-264. 


\section{No. 2. A Network with More Distant Regions (Macedonia, Epirus, the Aegean Islands and the West Coast of Asia Minor)}

Number of sources revealing profession and origin of honorand(s): 33 decrees and 6 tituli honorarii. $^{2}$

TABLE 3 Chronological distribution of texts

Date No. of sources

\begin{tabular}{lr}
\hline 4th century вСЕ & 7 \\
3rd century ВСЕ & 11 \\
2nd century ВСЕ & 3 \\
1st century BCE & 2 \\
1st century CE & 5 \\
2nd century CE $^{\text {Imp. }}$ & 5 \\
Undated & 5 \\
\hline
\end{tabular}

a This category includes inscriptions dated by the editors as imperial texts without any further date.

2 All tituli honorarii honour citizens of Nikopolis (Syll ${ }^{3} 874 \mathrm{~B}$, Syll ${ }^{3} 791 \mathrm{C} ; \mathrm{BCH}_{75.1951 \cdot 307-8)}$. 
TABLE 4 Professions of honorands originating from more distant regions

\begin{tabular}{|c|c|c|c|c|c|c|c|}
\hline Profession & $\begin{array}{l}\text { 4th } \\
\text { century } \\
\text { BCE }\end{array}$ & $\begin{array}{l}\text { 3rd } \\
\text { century } \\
\text { BCE }\end{array}$ & $\begin{array}{l}\text { 2nd } \\
\text { century } \\
\text { BCE }\end{array}$ & $\begin{array}{l}\text { 1st } \\
\text { century } \\
\text { BCE }\end{array}$ & $\begin{array}{l}\text { 1st } \\
\text { century } \\
\text { CE }\end{array}$ & $\begin{array}{l}\text { 2nd } \\
\text { century } \\
\text { CE }\end{array}$ & Imp. \\
\hline Public officials & & 7 & & & 3 & & 1 \\
\hline Artists/musicians & & 4 & 2 & 1 & 1 & & 3 \\
\hline 'Men of letters' & 2 & & & & 1 & 3 & \\
\hline Foreign judges & & & 1 & & & & \\
\hline \multicolumn{8}{|l|}{ Priests/temple stuff } \\
\hline Athletes & & & & 1 & & & 1 \\
\hline Monarchs & Philip II $^{\mathrm{a}}$ & & & & & & \\
\hline Physicians & & & & & & 1 & \\
\hline Military commanders & 5 & & & & & & \\
\hline Other & & & & & & & \\
\hline
\end{tabular}

a $S y l l^{3}{ }_{221}$ C; $B C H$ 73.1949.258-26o. 


\section{No. 3. A Wide Network (the Propontic Areas, the Hellespont, the Black Sea Region, the South Coast of Asia Minor, Syria, Cyprus, Egypt and Magna Graecia)}

Number of sources revealing profession and origin of honorand(s): 53 decrees and 37 tituli honorarii.

TABLE 5 Chronological distribution of texts

\begin{tabular}{lc} 
Date & No. of sources \\
\hline 4th century BCE & 1 \\
\hline 3rd century BCE & 8 \\
2nd century BCE & 17 \\
1st century BCE & 14 \\
1st century CE & 16 \\
2nd century CE & 10 \\
Imp. & 23 \\
Undated & 1
\end{tabular}

a This category includes inscriptions dated by the editors as imperial texts without any further date. 
TABLE 6 Professions of honorands originating from a wide network

\begin{tabular}{|c|c|c|c|c|c|c|c|}
\hline Profession & $\begin{array}{l}4^{\text {th }} \\
\text { century } \\
\text { BCE }\end{array}$ & $\begin{array}{l}\text { 3rd } \\
\text { century } \\
\text { BCE }\end{array}$ & $\begin{array}{l}\text { 2nd } \\
\text { century } \\
\text { BCE }\end{array}$ & $\begin{array}{l}\text { 1st } \\
\text { century } \\
\text { BCE }\end{array}$ & $\begin{array}{l}\text { 1st } \\
\text { century } \\
\text { CE }\end{array}$ & $\begin{array}{l}\text { 2nd } \\
\text { century } \\
\text { CE }\end{array}$ & Imp. \\
\hline Public officials & & 3 & 4 & 1 & & & 1 \\
\hline $\begin{array}{l}\text { Artists/ } \\
\text { musicians }\end{array}$ & & 1 & 3 & & 4 & 1 & 3 \\
\hline 'Men of letters' & & 1 & & 1 & 1 & 4 & 6 \\
\hline Foreign judges & & & & & & & \\
\hline Priests/temple stuff & & 1 & & & & & \\
\hline Athletes & & & & & & & \\
\hline Monarchs ${ }^{\mathbf{a}}$ & $1^{b}$ & $3^{c}$ & $5^{\mathrm{d}}$ & $1^{e}$ & & & \\
\hline Emperors ${ }^{f}$ & & & & ${ }_{1}^{\mathrm{g}}$ & 6 & 3 & 10 \\
\hline Physicians & & & & 1 & 1 & & \\
\hline Roman officials & & & 4 & 8 & 3 & 1 & 5 \\
\hline Other & & & & \multicolumn{4}{|c|}{ astrologer ${ }^{\mathrm{h}}$} \\
\hline
\end{tabular}

a Along with the royal court.

b Decree honouring four sons of Kersebleptes, the Thracian king ( $F d D$ 1.392; Choix 2012, no. 46).

c One decree honouring the Attalids ( $F d D$ 1.432; Kotsidu 200o, no. 9o; Choix 2012, no. 65); one decree for Kotys III, the Odrysian king of Thrace, son of Raizdos (FdD 4.414; Kotsidu 200o, no. 99; Choix 2012, no. 72); and one decree honouring king Seleukos II ( $F d D$ 4.153; Rigsby 1996, no. 7; Kotsidu 200o, no. 88; Choix 2012, no. 81).

d One decree for a friend of Ptolemy vi (FdD 4.161; Choix 2012, no. 169); one decree for the king Eumenes II (FdD 3.237, Choix 2012, no. 165); one honorific inscription for Attalos II (FdD 3.121); one honorific decree honouring Pairisades IV, the king of Bosporus and his mother, queen Kamasarye, daughter of king Spartokos VI ( $F d D$ 1.453; Kotsidu 200o, no. 102); and one decree for a member of the royal court of Antiochos III (?) (SGDI 2677; Nachtergael 1977, no. 36).

e Honorific decree honouring the king Nikomedes III of Bithynia and queen Laodike, daughter of Mithridates V ( FdD 4.77; Rousset 2002, Insc. 31; Choix 2012, no. 185).

$\mathrm{f}$ Along with the members of the imperial family and the royal court.

g Gaius Suplicius Galba, father or grandfather of the emperor (FdD 4.438; Chaniotis 1988, E45).

h $\quad$ Syll 771 . 